\title{
CONTEMPORARY FINANCIAL CONTROL: CHALLENGES, CONTRADICTIONS AND DIGITAL TOOLS FOR DEVELOPMENT
}

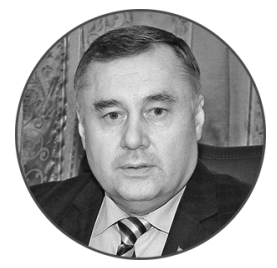

\author{
Arsen A. TATUEV \\ Kabardino-Balkarian State University named after H.M. Berbekov, \\ Nalchik, Kabardino-Balkar Republic, Russian Federation \\ arsen.tatuev@mail.ru \\ https://orcid.org/0000-0002-6900-9770

\section{Corresponding author}

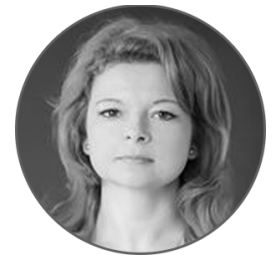

\section{Nataliya I. OVCHAROVA}

Surgut State University (SurGU), Surgut, Khanty-Mansi Autonomous Okrug, Russian Federation ovcharova@box.ru

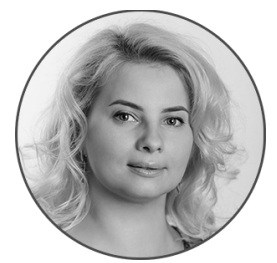

\section{Oksana N. GALYUTA}

Surgut State University (SurGU), Surgut, Khanty-Mansi Autonomous Okrug, Russian Federation galuta@me.com

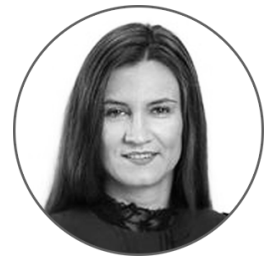

\author{
Mariya A.ZALEVSKAYA \\ Surgut State University (SurGU), \\ Surgut, Khanty-Mansi Autonomous Okrug, Russian Federation \\ 3alevskaya@gmail.com
}

\section{Article history:}

Received 5 September 2018

Received in revised form 20 September 2018

Accepted 4 October 2018

Translated 14 January 2019

Available online 29 March 2019

JEL classification: G00, G29

Keywords: fiscal control, financial system, financialisation, digitization, digital financial infrastructure, blockchain platform

\begin{abstract}
Subject This paper discusses the perspective development of modern financial control instruments due to the increasing digitization of the financial system. The paper also examines the challenges and contradictions facing financial control at the present time.

Objectives The paper aims to justify the need for advanced financial control through embedding in the ecosystems of financial markets and digital financial infrastructure with the preservation and development of its external character. Methods For the study, we used methods of generalization and structural design.

Results The paper says that the main contradiction of the modern financial control is the increasing discrepancy of its organizational and managerial forms to the challenges of financialisation and digitization. The paper proposes to form adapted digital instruments.

Conclusions and Relevance Development of priorities of modern financial control is involves its new organization on the basis of principles of openness, permanence and universality of all participants of financial relations. The results obtained can be used to supplement the implemented main directions of financial technologies development with the system set of digital instruments of financial control.
\end{abstract}


Growing outstrippingly fast, financial components play a special tole among multiple characteristics of the recent economic development (post-industrial, economy of knowledge, digital, etc.), which are differently construed by scholars and experts. The latter fact is almost generally accepted.

As financial components grow systemically important for business operations, the substance and forms of financial relationships have a tendency to gradually transform as well. On the one hand, no changes are seen in the main characteristics of financial relationships, such as the monetary form, stringent purpose and use, link to distributing and redistributing tools and institutions. On the other hand, the economic environment and totality of designation and practical use goals undergo crucial changes, that cannot but influence the substance.

Finance and financial relationships are conventionally believed to translate their substance though their systemic functions of national reproduction. Notwithstanding the existing variety of functions finance play, there are two fundamental ones, i.e. distribution and control.

The distribution function is known to stem from the need to allocate results of economic activities (new value added, gross domestic product, etc.) in line with the public and national demand, which depends on primary, secondary and ultimate flows of income. Money serves to control that income from distribution processes throughout levels of financial relationships be completely, correctly and timely utilized, thus having an organizational effect on the financial control system. As pointed out in some cases, functions of finance, which include stimulation, stabilization, taxation, accumulation and so on, are actually derivative or hybrid of relationships typical of other economic relationships.

Digital development processes gain momentum in the time of a considerable socio-economic transformation, thus altering the substance of both functions. However,

${ }^{\dagger}$ For the source article, please refer to: Татуев А.А., Овчарова Н.И., Галюта О.Н., Залевская М.А. Современный финансовый контроль: вызовы, противоречия и цифровые инструменты развития // Финансы и кредит. 2018. Т. 24. № 12. С. 2661-2677. URL: https://doi.org/10.24891/fc.24.12.2661 while the first primarily entails further improvement and development of distribution processes throughout levels of financial relationships, the latter changes drastically. The reasons is that financial control strongly implies forecasting, collection of the complete information about the formation of funds, their stringent and purposeful use, and its effective processing. It is hard to deny that there should be proper conditions for big data processing. Therefore, organizational principles of financial control should be amended respectively.

This is the function of control that faced new challenges brought about with the economic development. Those challenges include inter alia the financialization of economy nationally and globally [1, 2].

Generally, financialization blends key macroeconomic trends, i.e. an outstripping growth in gross domestic product (GDP) as seen for the recent decades and investment in the real economy (primarily in capital stock) [3]. Such a macroeconomic situation resulted from the public wellbeing that improved in advanced economies in the last fifteen years of the 20th century due to the performance of public capitalism principles among other things. People put aside an increasing amount of money during a long period of time, which was naturally represented with various securities and some other stock instruments. The process stalled only after the 2007-2009 financial crisis. The financial sector saw a respective upswing in investment deals respectively.

As mentioned in scholarly literature, the par value of global financial assets demonstrated a seven-fold increase during the 1995-2015 period, from USD 42 up to 294 trillion. The increase was concomitant with a growth in the ratio of the assets to global GDP, from $195 \%$ up to $375 \%$. These trends were slightly affected by the global financial crisis since they continued to prevail. The growing ratio of financial assets to investment in fixed capital became one of the hallmarks of the post-crisis recovery. The capitalization of stock markets of the USA, European Union, United Kingdom and Japan almost doubled within the period from 2009 through 2015, while total assets of central banks showed a 1.5-fold increase [4]. Steadily rising financial flows against a growth in the real economy, which 
currently gain momentum, being noted in the report of the UN experts' on trade and development ${ }^{1} 1$.

Such trends took their course in the Russian economy, however being more distorted in some cases. The processes turned to be especially dramatic concerning the ratio of investment in non-financial assets to financial investment (Fig. 1).

On the one hand, the situation illustrates interpretations of economic crises, which were common in the late 20th century. According to such interpretations, a cause-and-effect relationship arises when financial relationships based on the development and stability of the system morph into those ones pursuing the speculative income during the period of active economic growth, thus undermining the stability of the national economy [5].

As parties to financial relationships rearrange their goals during the seemingly sufficient economic growth, the market sees the expansion of speculative financial assets saved, respective debts with underestimated risks. This, first directly and subsequently indirectly, paves the transition from hedged leverage to speculative forms of debt financing [6]. The market value of speculative assets unavoidably decreases, triggering the active deployment of the Ponzi scheme (financial pyramid) or sale of similar assets and obvious impairment of all types of assets. Both processes shatter the financial stability of the economic system.

On the other hand, it is worth mentioning herein that the specific problem of financial control arises when many budgetary expenditures convert into speculative financial assets. Refer to Fig. 1 again to see that trillions the State injects into the banking system of Russia during the global financial crisis and sanctions imposed had almost not decreased a percentage of non-financial investment. It means purposeful budgetary spending for supporting the national financial system does not contribute to the main goal of expanded reproduction and economic growth. It is arguable and disputable whether such budgetary spending can be deemed effective in terms of financial control.

The digitization of economic and social spaces is another systemically important challenge for social development, which has a tremendous effect on financial control aspects. The concept of digital economy is not yet clearly defined, being perceived

\footnotetext{
${ }^{1}$ World Investment Report 2016.

URL: http://unctad.org/en/PublicationsLibrary/wir2016_en.pdf
}

through digital technologies used in production and manufacturing processes. Thus, in this case, we adhere to the definition of digital economy set forth in the Program, Digital Economy of the Russian Federation, as approved with Instruction of the RF Government of July 28, 2017 № 1632-p. Digital economy is understood there as an economic activity driven with data in the digital form as its key factor of production. This frames the information space in accordance with the need of citizens and society as a whole to get proper and accurate information, development the information infrastructure of the Russian Federation, creates and implements the Russian ICT, new technological platform for the social and economic life.

The above definition definitely lacks some substantive principle, other than that the digital economy is defined through the lens of prevailing technologies, i.e. digital economy - digital technologies. In the course of time, there will be sufficiently theoretical and empirical grounds to make more meaningful definitions as it happened with the interpretation of agricultural, industrial, post-industrial economy, etc.

The approach to financial aspects is based on similar logic. As set forth by the Central Bank of Russia in Principal Areas for the Development of Financial Technologies for the 2018-2020 Period in the context of the program, Digital Economy of the Russian Federation, Big Data, data analysis, mobile technologies, artificial intelligence, robotification, biometrics, distributed ledger, cloud technologies are prioritized for the financial system.

The Accounts Chamber released the 2018-2024 Development Strategy approved by its Board as part of general development paths and methodology for statutory audit and internal system of governance, human resources and organizational culture. The Strategy provides for the implementation and development of modern digital technologies for statutory audit. Following this course, first, the Accounts Chamber is supposed to carry out the digitization of its operations by creating the digital infrastructure to support the auditing and analytical practices, advance remote auditing methods, refine mechanisms and procedures for getting the feedback from the public and users of information via the digital infrastructure. Second, the Accounts Chamber should facilitate the digital transformation of the public administration through performance audit and strategic audit of governmental information systems and public data 
processing systms. It should also provide guidelines for the digitization of public administration, development of governmental information systems, implementation of analytical and decision support systems based on data.

Moreover, almost every program implies digital technologies. Such a dedicated approach makes things about financial control more complicated because key substantive criteria for the purposeful and effective use of financial resources are left out of scope in modernizing the financial system and its controlling bodies. Therefore, in the current circumstances, it is important to establish new digital financial relations as the general systemic goal and a goal of the financial control development.

We should note the totality of financial market trends as the third challenge to the economic development today $^{2}$. They are observed in the Russian segment as well. These are low margin of banking services, financial market actors transforming their business models and striving to create the environment, broader availability of financial services due to their digital format, banks' loss of monopoly over traditional services (payment and other) and non-financial entities playing a considerable role in the financial market, banks' intention to set up partnership relationships with startups and technological companies.

The formation of the low margin financial business environment should be under special scrutiny. Financial entities are actively adapting to such working conditions. However, for purposes of this research, we should emphasize that financial control gets on the rise in the time of low economic growth and low margin. In such situations, total breaches and violations block financial resources needed for growth. To teeter between development and stagnation, there should be effective and robust financial control with the predominant analytical function.

The key contradictory feature of financial control arises, with the unfolding challenges on the background.

Currently, financial control transforms into one of the most conservative economic practices. The rise of transformational processes in financial relations and predominant preservation of the existing financial control approaches come into collision that gradually deteriorates. On the one hand, the collision results in

\footnotetext{
${ }^{2}$ Key Areas for Developing Financial Technologies within the 2018-2020 Period. Moscow, Central Bank of Russia Publ., 2018, p. 3.
}

the space of new financial relations, which are actually beyond effective financial control. On the other hand, audits become less effective and relevant.

It should be kept in mind that financial control issues should be considered through the lens of a dramatic change in systemic priorities of the Russian economy. In particular, the academic community continues active debates about the need to articulate a new conceptual doctrine of socio-economic development as the contemporary social development poses an increasing number of questions and problems [7, 8]. Scholars say negative factors of the contemporary world (recent recession and foreign sanctions) need to be eliminated [9-11], which respectively concern the development of financial relations. Researchers put effort into overcoming a decline in sectoral investment [12], searching new regional development tools ${ }^{3}$, ensuring the effective use of people's savings [13].

Considering the future of financial relations, we would like to indicate a well-reasoned opinion that the new economy will prioritize the creation, rather than reproduction. Hence, views on the future should encompass the coming creative revolution more than reindustrialization, which is on the top of current debates [14].

The expanding functional role of creative work may resemble the transformation of the computer industry when it became one of the main growth areas. Growing rapidly, the computer industry constantly produces new technological means and tools for the permanent creation of new products and services [15]. Moreover, it is interesting to observe that the systemic expansion of the digital sector is thought to result from rather active expansion of the so called transaction sector integrating multiple types of creative activities, i.e. public administration, finance, information support, consulting, servicing, etc. ${ }^{4}$

As we presume from perspectives of the subject herein, this generates new financial relationships and tools for any new investment or production project. Standardized schemes were previously used to render key financial services but now the standardization level

\footnotetext{
${ }^{3}$ Shanin S.A. [Regional investment policy: Contemporary approaches and modernization trends]. Belgorodskii ekonomicheskii vestnik = Belgorod Bulletin of Economics, 2012, no. 3, pp. 16-22. (In Russ.)

${ }^{4}$ Savina T.N. [Digital economy as a new paradigm of development: Challenges, opportunities, and prospects]. Finansy $i$ Kredit = Finance and Credit, 2018, vol. 24, no. 3, pp. 579-590. (In Russ.)

URL: https://doi.org/10.24891/fc.24.3.579
} 
subsides, with the novelty growing much more significant in each particular case.

Concurrently with the trends, the substance and methods of financial control remain rather conservative, though being constantly updated for certain aspects.

In its more generalized presentation, financial control is perceived through a set of various types, forms and methods. When its substance is formalized through the legally regulated practice of checking the compliance with standards and requirements for effective planning, collection and use of monetary funds, it seems the most important institutions ensuring the legitimacy of financial operations and related business activities.

Financial control is within the competence of federal and municipal authorities, independent auditors and auditing forms, law enforcement bodies, internal functions of business entities. Any kind of control is generally deemed effective if the amount reimbursed and monetary and material loss prevented significantly exceed the costs incurred to organize and carry out such control [16].

The government arranges for financial control over certain aspects, which are legislatively stipulated (performance of the federal budget, money circulation process, use of debt resources and some other). Financial control is the responsibility of the Accounts Chamber of the Russian Federation, Central Bank of Russia, Ministry of Finance of the Russian Federation, Federal Service for Currency and Export Control and some other ministries and agencies. Internal control is mostly performed by accounting, financial and economic departments. Banking control of financial and credit institutions deserves a special mention since the Central Bank of Russia is authorized to conduct a wide spectrum of oversight and supervisory activities.

Control more often than not may be public (intentional efforts of citizens, political parties, mass media, public associations, etc.), independent (a set of certified auditing firms), current (ongoing activity of financial functions at all levels), follow-up (internal and independent audits of financial operations for past periods). Methods of observation, audit, examination, analysis, revision are most frequent and effective. Revision is considered as the principal method which laws abide to conduct on a statutory and regular basis. The revision is classified into documentary and factual, scheduled and extraordinary, complete and samplebased, comprehensive or dedicated.

Abstaining from disputes about the content, goals and effectiveness of financial control $[17,18]$, we can see an obvious indication to static methods and modes of operations. Hence, considering that businesses tend to creative systems of management and digital technology, there arises the main inconsistency of the contemporary financial control practice. Business and legal forms of financial control more and more come into disagreement with the priority content of financial relations. If such inconsistency persists, financial control will demonstrate low efficiency.

The fact that financial audits are insufficiently effective can be illustrated with data of the Accounts Chamber of the Russian Federation. For example, the scope of breaches, which auditors detect, is almost incomparable with reimbursable amounts. So, there is no direct correlation between a growth in breaches and reimbursable amounts (Table 1).

Furthermore, in 2017, actual federal fiscal revenue was 2.5 percent as high as estimates, while real expenditures were 1.8 percent as low as estimates. What attracts attention is that the deficit of federal budget turned to be 33.3 percent as low as the approved one (Table 2).

The average federal spending was 96.5 percent, with the considerable differentiation of certain sections (Table 3). The Accounts Chamber of the Russian Federation especially emphasized the need to undertake more efficient measures for better planning in line with real wants and even and effective use of budgetary funds.

What is more, financial control will be further enhanced by checking the reasonableness of key macroeconomic indicators of Russia's socio-economic development forecast for 2019 and the base period of 2020 and 2021. It is also necessary to confirm whether fiscal revenue is reasonably forecasted and budgetary expenditures are effectively incurred ${ }^{5}$. In the mean time, new organizational measures reflecting the development of digital technologies in the public and financial sectors are almost overlooked, though there are quite good examples of new technologies in use.

\footnotetext{
${ }^{5}$ Report on the performance of the Accounts Chamber of the Russian Federation in 2017. Moscow, Accounts Chamber of Russian Federation Publ., 2018, 205 p.
} 
Russia is known to implement the joint project of the Ministry of Finance and open government, The Budget for Citizens. Currently, the open budget is predominantly considered as a platform for information support and productive dialogue between respective governmental officials and the population on the administration of public financial resources.

Moreover, we should mention that the efficacy of financial control is questionable in the case of business entities. Some researches point out that the national investment segment, especially capital expenditures on capital stock, is sluggish, which almost prevents adequate digitization reforms. As the effective Russian laws prescribe, control demonstrates the disparity. On the one hand, funds the State earmarks for investment purposes are directly subject to control. On the other hand, it is almost impossible to effectively control how entities utilize their equity for capital expenditures. It is especially true when internal auditors need to identify what mainly triggered fraud in the corporate governance system ${ }^{6}$.

We believe that this particular situation represents the paradox of financial control, significantly affecting the potential of public-private partnerships. While publicprivate partnership abroad revitalizes investment activities and makes it more effective, the expansion of the mechanism in Russia has no palpable effect on the investment process.

Therefore, financial control cannot evolve without digital technologies. Moreover, financial control should intrude into the financial system so that its outer substance would remain unchanged and continue to evolve. Financial control should apply to all parties to financial relationships, especially in the context of blockchain. As scholarly literature puts it, new technologies make the economic construct of confidence transform, extensive practice of financial intermediation subsides and people get more involved into financial relationships [19].

As we see it, it would be effective to fit the integral financial control system into the measures stipulated in The Key Areas for the Development of Digital Technologies for the 2018-2020 Period and the program, Digital Economy of the Russian Federation.

This will arrange the practice of financial control in a new way, making it open, continuous and involving all parties, rather than revision commissions, internal auditors, accounts chambers only, etc.

The neural blockchain platform for financial control should be built in the relationships between respective parties and environments of the financial market and digital financial infrastructure in order to implement the above (Fig. 2 and 3).

The blockchain technology is a sequence of blocks representing real transactions of parties operating in the system. The blockchain technology increases the functional role of each participant as one of its main results and effects, which will especially matter for financial control.

Based on digital technologies, its common and continuous format, financial control will reduce the unintended use of limited financial resources and substantially morph into the practice of performance analysis.

\footnotetext{
${ }^{6}$ Smetanko A.V., Kulyakina E.L. [Risk-based internal audit in the system of signs and causes of fraud identification]. Finansy $i$ Kredit $=$ Finance and Credit, 2018, vol. 24, no. 4, pp. 755-766. (In Russ.) URL: https://doi.org/10.24891/fc.24.4.755
} 


\section{Table 1}

Some performance indicators of the Accounts Chamber of the Russian Federation, 2015-2017

\begin{tabular}{|c|c|c|c|}
\hline Indicators & 2015 & 2016 & 2017 \\
\hline Controlling, expert and analytical checks, total & 322 & 321 & 319 \\
\hline Breaches detected during statutory audit (control), billion RUB & 516.5 & 965.8 & $1,865.6$ \\
\hline $\begin{array}{l}\text { Amounts reimbursed to budgets of all the fiscal levels of the Russian Federation and system of the } \\
\text { Union State, million RUB }\end{array}$ & 10,317 & $8,816.8$ & $19,151.7$ \\
\hline
\end{tabular}

Source:Authoring, based on Otchet o rabote Schetnoi Palaty Rossiiskoi Federatsii v 2017 godu [Report of Accounts Chamber of the Russian Federation in 2017]. Moscow, Accounts Chamber of the Russian Federation Publ., 2018, pp. 7-8

\section{Table 2}

Some macroeconomic indicators and description of changes in the federal budget of the Russian Federation for FY 2017 and their factual performance

\begin{tabular}{|c|c|c|c|c|c|}
\hline \multirow[t]{2}{*}{ Indicator } & \multicolumn{4}{|c|}{ Federal budget for FY 2017 adjusted and approved by Federal Law } & \multirow{2}{*}{$\begin{array}{l}\text { Factually } \\
\text { performed in } 2017\end{array}$} \\
\hline & $\begin{array}{l}\text { of 01.12.2014 № } \\
\text { 384-Ф3 }\end{array}$ & $\begin{array}{l}\text { of 19.12.2016 № } \\
415-Ф 3\end{array}$ & $\begin{array}{l}\text { of 01.07.2017 № } \\
157-Ф 3\end{array}$ & $\begin{array}{l}\text { of 14.11.2017 } \\
\text { № 326-Ф3 }\end{array}$ & \\
\hline GDP, billion RUB & 90,063 & 86,806 & 92,190 & 92,224 & $92,081.9$ \\
\hline Inflation rate, $\%$ & 4 & 4 & 3.8 & 3.2 & 2.5 \\
\hline Revenue, billion RUB & $16,547.8$ & $13,487.6$ & $14,678.8$ & $14,720.3$ & 15,087 \\
\hline Percentage of GDP & 18.4 & 15.5 & 15.9 & 15.96 & 16.4 \\
\hline Expenditures, billion RUB & $17,088.7$ & $16,240.8$ & $16,602.6$ & $16,728.4$ & $16,425.8$ \\
\hline Percentage of GDP & 19 & 18.7 & 18 & 18.1 & 17.8 \\
\hline $\begin{array}{l}\text { Budget deficit (-)/ surplus (+), billion } \\
\text { RUB }\end{array}$ & -540.9 & $-2,753.2$ & $-1,923.8$ & $-2,008.1$ & $-1,338,8$ \\
\hline
\end{tabular}

Source:Authoring, based on Analiticheskaya zapiska o khode ispolneniya federal'nogo byudzheta i byudzhetov gosudarstvennykh vnebyudzhetnykh fondov Rossiiskoi Federatsii za yanvar'-dekabr'2017 goda [Analytical Note on the Progress of the Federal Budget and the Budgets of State Extra-Budgetary Funds of the Russian Federation for January-December 2017]. (In Russ.) 


\section{Table 3}

Analysis of federal spending by section for January-December 2016-2017, billion RUB

\begin{tabular}{|c|c|c|c|c|c|c|}
\hline \multirow[t]{3}{*}{ Indicator } & \multicolumn{3}{|l|}{2016} & \multicolumn{3}{|l|}{2017} \\
\hline & \multirow[t]{2}{*}{ Approved } & \multicolumn{2}{|c|}{$\begin{array}{l}\text { Performed from Jan } \\
\text { thru Dec }\end{array}$} & \multirow[t]{2}{*}{ Approved } & \multicolumn{2}{|c|}{$\begin{array}{l}\text { Performed from Jan } \\
\text { thru Dec }\end{array}$} \\
\hline & & Amount & $\%$ & & Amount & $\%$ \\
\hline General national needs & $1,127.8$ & $1,095.6$ & 97.1 & $1,248.3$ & $1,167.2$ & 93.5 \\
\hline National defense & $3,806.4$ & $3,775.4$ & 99.2 & $3,059.6$ & $2,852.8$ & 93.2 \\
\hline National security and law enforcement & $1,891.8$ & $1,898.7$ & 100.4 & $1,960.8$ & 1,918 & 97.8 \\
\hline National economy & $2,401.6$ & $2,302.1$ & 95.9 & $2,580.2$ & 2,460 & 95.3 \\
\hline Housing and utilities services & 75.7 & 72.2 & 95.5 & 124.9 & 119.5 & 95.6 \\
\hline Environmental protection & 63.4 & 63.1 & 99.6 & 93.1 & 92.4 & 99.2 \\
\hline Education & 603.2 & 597.8 & 99.1 & 623.1 & 615 & 98.7 \\
\hline Culture, cinema & 90.6 & 87.3 & 96.3 & 98.4 & 89.7 & 91.1 \\
\hline Healthcare & 518.6 & 506.3 & 97.6 & 451.9 & 439.9 & 97.4 \\
\hline Social policy & $4,600.3$ & $4,588.5$ & 99.7 & 5031.3 & $4,992.1$ & 99.2 \\
\hline Physical culture and sports & 67.2 & 59.6 & 88.7 & 102.5 & 96.1 & 93.8 \\
\hline Mass media & 76.7 & 76.7 & 99.9 & 83.3 & 83.2 & 99.9 \\
\hline Public and municipal debt & 639.6 & 621.3 & 97.1 & 730.3 & 709.2 & 97.1 \\
\hline $\begin{array}{l}\text { General cross-budgetary transfers to budgets of the constituent } \\
\text { entities of the Russian Federation and municipalities }\end{array}$ & 673.7 & 672 & 99.8 & 829.3 & 790.7 & 95.3 \\
\hline Federal budgetary spending, total & $16,636,4$ & $16,416,5$ & 98,7 & $17,016,9$ & $16,425,8$ & 96.5 \\
\hline
\end{tabular}

Source:Authoring, based on Analiticheskaya zapiska o khode ispolneniya federal'nogo byudzheta i byudzhetov gosudarstvennykh vnebyudzhetnykh fondov Rossiiskoi Federatsii za yanvar'-dekabr'2017 goda [Analytical Note on the Progress of the Federal Budget and the Budgets of State Extra-Budgetary Funds of the Russian Federation for January-December 2017]. (In Russ.) 


\section{Figure 1}

Composition of investment in the Russian Federation

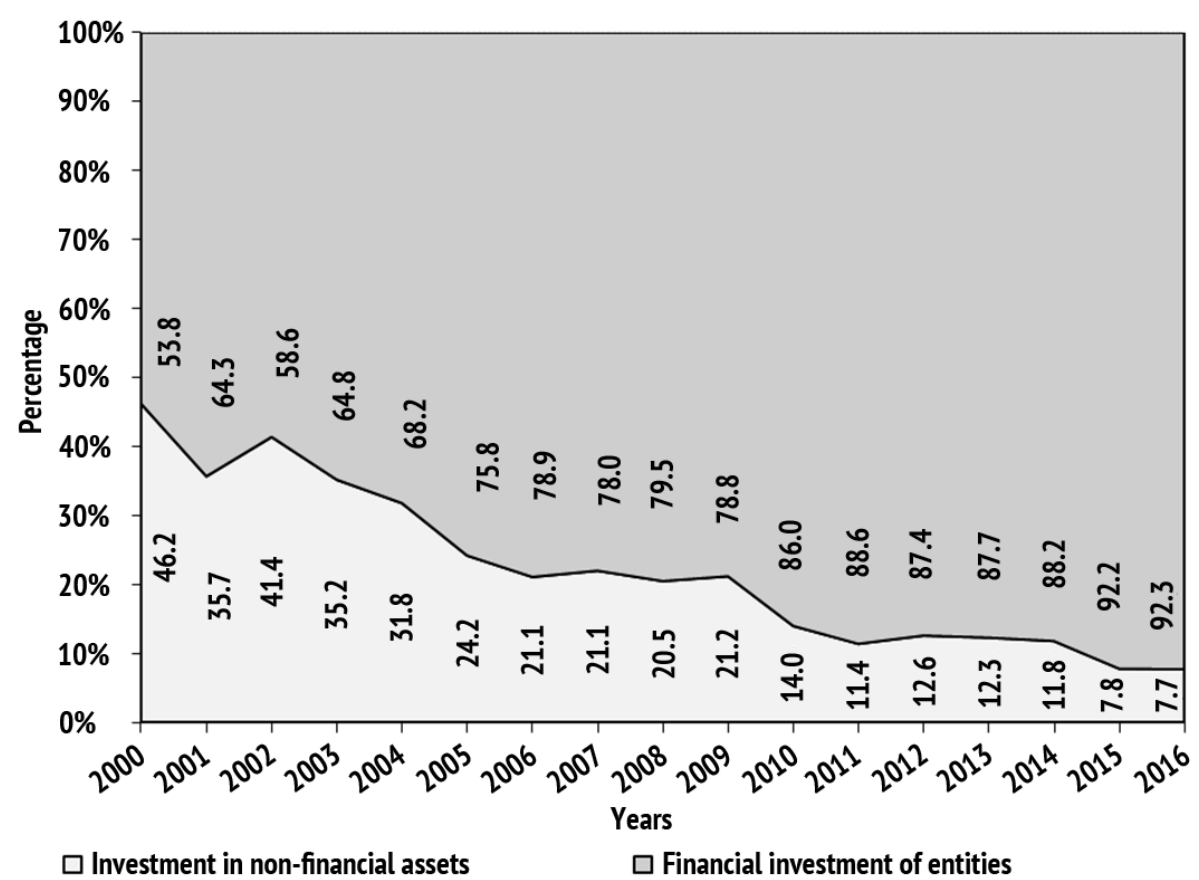

Source:Authoring, based on Investitsii v nefinansovye aktivy: Federal'naya sluzhba gosudarstvennoi statistiki [Investments in Non-Financial Assets: Federal State Statistics Service].URL: http://www.gks.ru/wps/wcm/connect/rosstat_main/rosstat/ru/statistics/enterprise/investment/nonfinancial/ (In Russ.) 
Figure 2

An action plan to create and develop the financial infrastructure

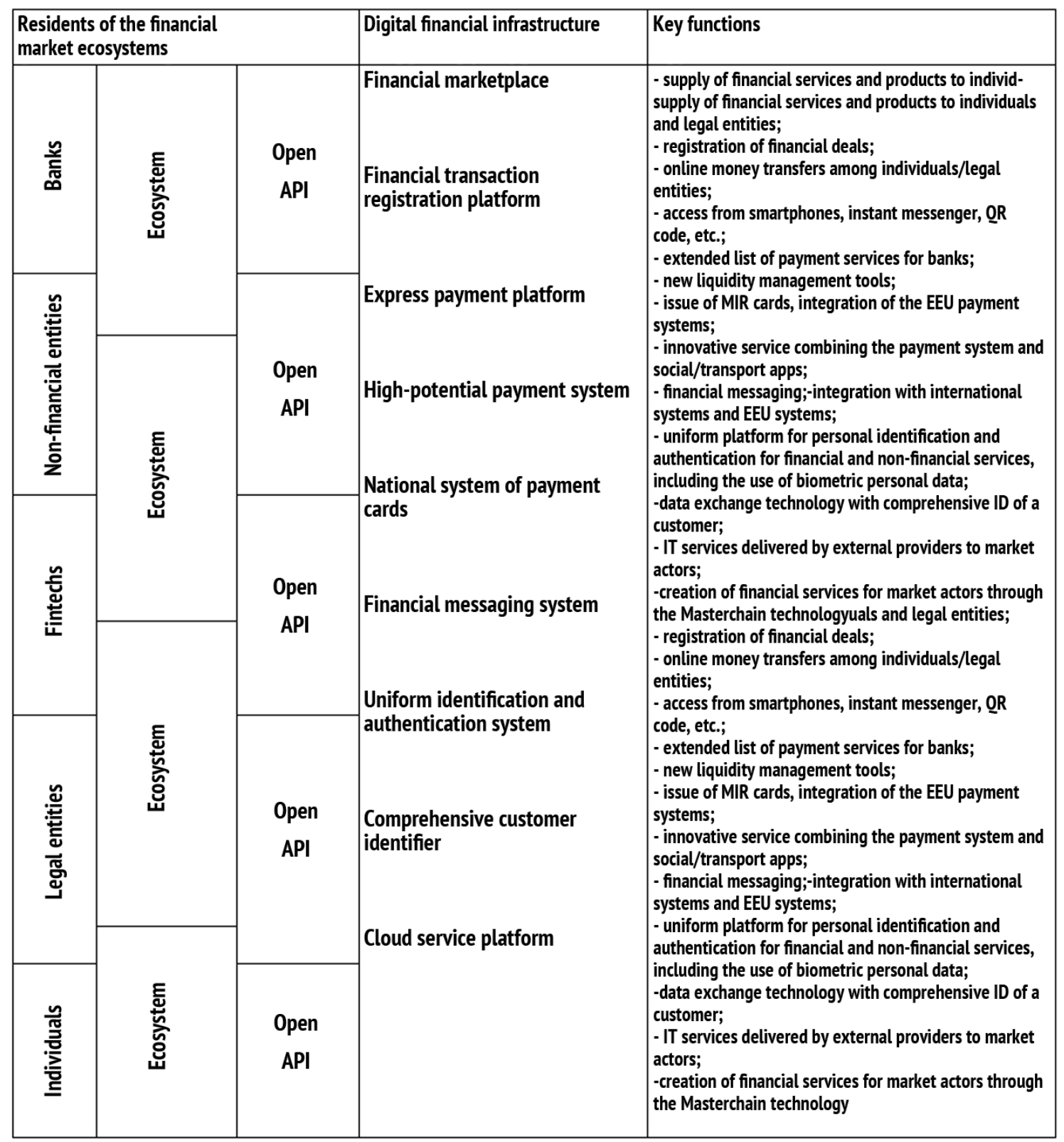

Source:Authoring, based on Osnovnye napravleniya razvitiya finansovykh tekhnologii na period 2018-2020 godov

[The Main Directions of Development of Financial Technologies for the Period 2018-2020]. Moscow, Central Bank of the Russian Federation Publ., 2018, pp. $12-14$

Please cite this article as: Tatuev A.A., Ovcharova N.I., Galyuta O.N., Zalevskaya M.A. Contemporary Financial Control: Challenges, 


\section{Figure 3}

The scheme of the embedded neural blockchain platform for financial control from all parties to financial systems

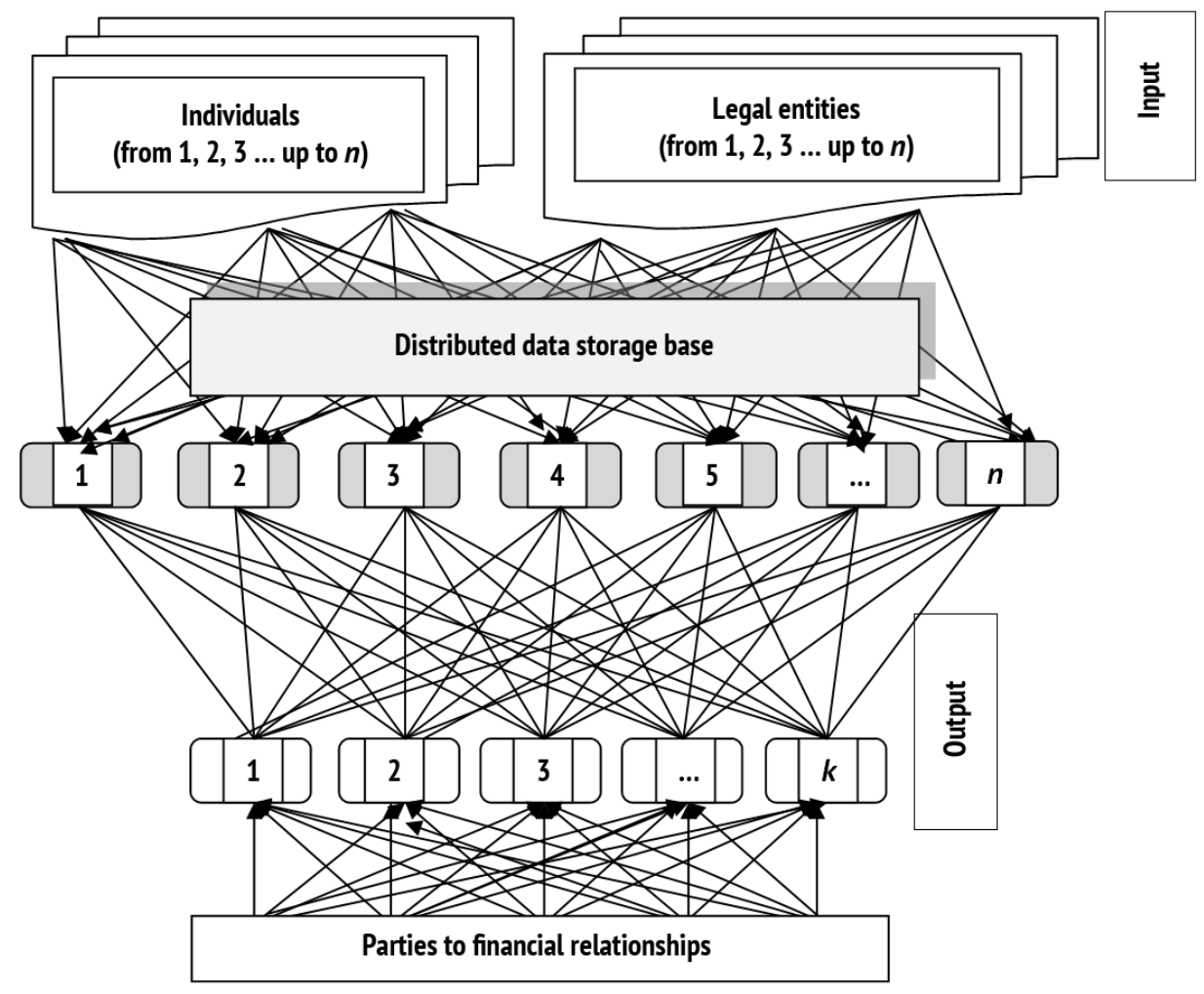

Source:Authoring

\section{References}

1. Bulgakova A.V., Denikaeva R.N. [The origin of the global financial crisis: its implications and "lessons"]. Ekonomika i upravlenie: problemy, resheniya = Economics and Management: Problems, Solutions, 2016, vol. 2, iss. 4, pp. 39-44. (In Russ.)

2. Kiyutsevskaya A., Trunin P. [Evolution of Global Governance: Learned Lessons of the Global Financial and Economic Crisis?]. Ekonomicheskoe razvitie Rossii = Russian Economic Developments, 2016, vol. 23, iss. 9, pp. 48-53. (In Russ.)

3. Misanova I.N. [About the question of financial aspects of the economic crises evolution]. Finansovaya ekonomika = Financial Economy, 2017, no. 2, pp. 47-52. (In Russ.)

4. Paunovich I. [Global Economic Governance in Need of Reform: How to Make the International Financial Architecture Work for Development]. Den'gi $i$ kredit = Money and Credit, 2016, no. 2, pp. 12-23. URL: http://www.cbr.ru/Content/Document/File/26547/paunovich_02_16.pdf (In Russ.)

5. Minsky H.P. The Financial Instability Hypothesis. The Jerome Levy Economics Institute Working Paper, 1992, no. 74, 48 p. URL: https://doi.org/10.2139/ssrn.161024

6. Dubinin S.K. [Financialization of Economic Growth and the Russian National Financial System]. Finansy: teoriya i praktika = Finance: Theory and Practice, 2017, vol. 21, iss. 4, pp. 6-21.

URL: https://financetp.fa.ru/jour/article/viewFile/1/39 (In Russ.) 
7. Blyakhman L.S. [Global Crisis and Change in the Paradigm of Economic Development]. Vestnik SanktPeterburgskogo universiteta. Seriya 5. Ekonomika = Vestnik of Saint Petersburg University. Economic Studies, 2013, no. 2, pp. 3-21. URL: https://cyberleninka.ru/article/n/globalnyy-krizis-i-smena-paradigmy-ekonomicheskogorazvitiya (In Russ.)

8. Akindinova H.V., Kuz'minov Ya.I., Yasin E.G. [Russia's economy: before the long transition]. Voprosy Ekonomiki, 2016, no. 6, pp. 5-35. (In Russ.)

9. Aganbegyan A.G. [Russian Economy: From Stagnation to Recession]. Den'gi $i$ kredit = Money and Credit, 2016, no. 5, pp. 10-20. (In Russ.)

10. Borisova I.Yu., Zamaraev B.A., Kozlova I.G. et al. [Russian economy under the pressure of sanctions and cheap oil]. Voprosy Ekonomiki, 2016, no. 7, pp. 5-35.

URL: http://institutiones.com/general/2883-rossiiskaya-ekonomika-pod-gnetom-sankcii-i-deshevoi-nefti.html (In Russ.)

11. Gurvich E.T., Prilepskii I.V. [The impact of financial sanctions on the Russian economy]. Voprosy Ekonomiki, 2016, no. 1, pp. 5-35. URL: http://institutiones.com/general/2729-vlyanie-finansovyx-sankcii-na-rossiiskuyuekonomiku.html (In Russ.)

12. Galazova S.S. [Guidance system investment industry policy for example industry]. Vestnik Severo-Osetinskogo gosudarstvennogo universiteta imeni K.L. Khetagurova, 2013, no. 2, pp. 204-209. (In Russ.)

13. Tatuev A.A., Bakhturazova T.V. [Modern role of household savings: Controversies and reality]. Vestnik instituta Druzhby narodov. Teoriya ekonomiki i upravleniya narodnym khozyaistvom, 2014, no. 3, p. 23. (In Russ.)

14. Buzgalin A.V. [The decline of neo-liberalism (to the 200th birth anniversary of Karl Marx)]. Voprosy Ekonomiki, 2018, no. 2, pp. 122-141. URL: http://institutiones.com/general/3113-zakat-neoliberalizma.html (In Russ.)

15. Prasolov V.I. [The digital economy as a response to the challenges of the XXI century]. Ekonomika i obshchestvo, 2017, no. 2, pp. 44-52. URL: http://scipress.ru/economy/articles/tsifrovaya-ekonomika-kak-otvet-na-vyzovykhkhi-veka.html (In Russ.)

16. Voronin Yu.M. [On State (municipal) financial control]. Finansy = Finance, 2014, no. 6, pp. 40-46. (In Russ.)

17. Salikhov Z.A. [Some approaches to an evalution of efficiency and productivity of work of bodies of the state financial control]. Audit i finansovyi analiz = Audit and Financial Analysis, 2005, no. 2, pp. 15-23. URL: http://www.auditfin.com/fin/2005/2/Salihov/Salihov\%20.pdf (In Russ.)

18. Litvinenko I.N., Shevtsov V.V. [Efficiency evaluation of the state financial control]. Novoe slovo $v$ nauke: perspektivy razvitiya, 2015, no. 2, pp. 374-377. (In Russ.)

19. Korneichuk B.V. [Political economy of distributed capitalism (On the book by D. Tapscott and A. Tapscott "Blockchain revolution. How the technology behind bitcoin is changing money, business, and the world")]. Voprosy Ekonomiki, 2018, no. 3, pp. 153-160. (In Russ.) URL: https://doi.org/10.32609/0042-8736-2018-3-153-160

\section{Conflict-of-interest notification}

We, the authors of this article, bindingly and explicitly declare of the partial and total lack of actual or potential conflict of interest with any other third party whatsoever, which may arise as a result of the publication of this article. This statement relates to the study, data collection and interpretation, writing and preparation of the article, and the decision to submit the manuscript for publication. 